\title{
Species sorting drives variation of boreal lake and river macrophyte communities
}

\author{
J. Alahuhta1 ${ }^{1,3}$ J. Rääpysjärvi², S. Hellsten², M. Kuoppala² and J. Aroviita ${ }^{2}$ \\ ${ }^{1}$ University of Oulu, Department of Geography, P.O. Box 3000, FI-90014 University of Oulu, Finland \\ ${ }^{2}$ Finnish Environment Institute, Freshwater Centre, FI-90014 University of Oulu, Finland \\ ${ }^{3}$ Corresponding author. E-mail: janne.alahuhta@oulu.fi
}

Keywords: Aquatic plants, Dispersal, Finland, Euclidean distances, Metacommunity dynamics, Overland distances, Principle Coordinates of Neighbour Matrices, Spatial processes, Space, Stream networks.

\begin{abstract}
Metacommunity paradigms are increasingly studied to explain how environmental control and spatial patterns determine variation in community composition. However, the relative importance of these patterns on biological assemblages among different habitats is not well known. We investigated the relative roles of local, catchment and spatial variables based on overland and watercourse distances in explaining the variation of community structure of lake and river macrophytes in two large river basins at two spatial extents (within and across river basins). Partial redundancy analysis was used to explore the share of variability in macrophyte communities attributable to local environmental conditions, catchment land cover and space (generated with Principle Coordinates of Neighbour Matrices). We found that local variables had the highest effect on both lake and river macrophyte communities, followed by catchment variables. Space had no or only marginal influence on the community structure regardless of used distance measure. Total phosphorus, conductivity and turbidity of the local variables contributed most for lake macrophytes, whereas $\mathrm{pH}$ and color had largest independent contribution for variation in river macrophytes. Size of catchment area and proportion of lakes and agriculture were the most important catchment variables in both habitats. The strong importance of environmental control suggests that both lake and river macrophyte communities are structured by species sorting. This finding gives support to the validity of assessment systems based on the European Water Framework Directive.
\end{abstract}

\section{Introduction}

Community compositions have been increasingly studied in the context of metacommunities, which forms a mechanistic framework to explain the interdependence of local interactions (e.g., between species and the environment) and spatial patterns (e.g., dispersal) (Leibold et al. 2004, Logue et al. 2011, Heino et al. 2015). Freshwater assemblages are differently affected by these ecological gradients. Local environmental conditions are usually important and spatial limitation is lacking at regional scales for species with good dispersal capabilities, such as diatoms, macrophytes and macroinvertebrates (Soininen and Weckström 2009, Bennett et al. 2010, De Bie et al. 2012, Alahuhta et al. 2013). Oppositely, fish depend strongly on watercourses for dispersal, for which they are highly influenced by spatial processes at regional scales (Cottenie 2005, Heino 2011, De Bie et al. 2012). In addition, the relative roles of ecological processes in structuring freshwater organisms are fundamentally related to spatial extent. The importance of niche patterns often decreases at broader extents, because limited dispersal hinders species from tracking environmental variation. Due to the increased dispersal limitation, spatial patterns should, in turn, be more dominating at broader extents (Leibold et al. 2004, Heino 2011). However, the findings on freshwater metacommunities have recently shown context-dependency, meaning that different ecological gradients dominate at various regions and extents (Alahuhta and Heino 2013, Grönroos et al. 2013).

The definition of metacommunity also depends, for example, on the dispersal capabilities of biological assemblages and spatial extent. In freshwater ecosystems, requirement for water limits dispersal of aquatic species to new areas, and communities with strong dispersers can usually interact with each other from a wider area, thus constituting a metacommunity (Jacobson and Peres-Neto 2010, Heino et al. 2012). Key primary producers of freshwaters, aquatic macrophytes, have efficient colonization strategies and can disperse long distances via e.g., waterfowl (Santamaria 2002, Viana et al. 2013). Community composition of lake flora is often dominantly structured by environmental factors (Capers et al. 2010, O'Hare et al. 2012, Alahuhta and Heino 2013, Alahuhta et al. 2013), and niche patterns have alike been found to control river bryophyte communities (Heino et al. 2012) in the regional scales. However, the influence of environmental factors and spatial patterns on community composition of stream vascular plants is poorly known.

Lakes and rivers possess notably different habitat characteristics. Streams are characterised by continuous unidirectional flow and considerable fluctuations in discharge and 
related water level fluctuations that are basis for frequent natural disturbances and a potentially extensive variation in water chemistry (Wetzel 2001). Instead, lakes are more stable environments with less temporal variation in water chemistry and smaller water level fluctuations compared to lotic systems. Differences between community composition of lake and river habitats have been studied in recent years (Johnson et al. 2004, Robinsin and Kawecka 2005, Crump et al. 2007), however, the relative importance of environmental factors and spatial patterns on lake and river community compositions are not well-known. Soininen and Weckström (2009) found that both lentic and lotic diatoms were structured by environmental control in nearby study areas. For aquatic macrophytes, there is no previous evidence how niche and spatial patterns affect lake and river community compositions within the same study area.

In this study, we explored the relative importance of local environment, catchment land cover and space for variation in community composition of lake and river macrophytes in two adjacent river basins. We also investigated whether spatial variables based on overland (Euclidean) or watercourse distances can better explain spatial patterns for lake and river macrophytes between river basins. In addition, we examined how spatial extent affects the importance of environmental control and spatial structuring of aquatic macrophyte communities. We expected that environmental control should primarily explain the variation in community composition for both lake and river macrophytes, although the significance of environmental control would likely to vary between the habitats. Consistent patterns in both river basins would suggest that the same patterns were involved, whereas inconsistency in this sense would imply region and/or habitat dependent patterns (see Heino et al. 2012, Alahuhta and Heino 2013). It was also assumed that spatial variables based on watercourse distances instead of Euclidean distances should explain better complex spatial patterns for aquatic macrophytes between river basins (Landeiro et al. 2011, Padial et al. 2014). We further hypothesised that space should explain more variation in lake than river macrophyte communities, because dispersal through stream network is likely more efficient for river flora and lakes are more isolated (Riis 2008). Last, we anticipated that the strength of spatial patterns (based on overland distances) would be stronger in across than within river basins (Alahuhta and Heino 2013).

\section{Materials and methods}

\section{Macrophyte surveys}

We used river and lake macrophyte surveys from two boreal adjacent river basins in southern Finland, Vuoksi and Kymijoki (Fig. 1). 24 lakes and 22 river sites were surveyed in Vuoksi and 24 lakes and 25 river sites in Kymijoki river basin as a part of national monitoring program. We used all available river site surveys existing in the studied river basins, but the study lakes were randomly selected among larger lake data set (50-60 lakes per river basin). To maintain better comparability between lakes and river sites, we limited the number of lakes to match with that of river sites. In addition to separate river basins, we combined lakes and river sites across river basins together to study the effect of extent on macrophytes, because aquatic plants can also disperse across river basins via waterfowl and also via wind (e.g., Santamaria 2002, Soons et al. 2008). The number of lakes and river sites was 48 and 47 across river basins extent, respectively (Table 1).

Lake macrophytes were surveyed using a main belt transect method (Kanninen et al. 2013). Each five-metre-wide transect extends - perpendicularly to the shoreline - from the upper eulittoral to the outer depth limit of vegetation, or to the deepest point of the basin if vegetation covers the entire lake. The transect is divided into zones according to the dominant life-form or species. Lake macrophytes are observed by wading or by boat, with the aid of rake and hydroscope. The species are listed and visual abundance estimates (frequency and coverage) are made for each taxon. The number of transects varied between seven and 25 (mean $=14, \mathrm{SD}=3.6$ ) for Vuoksi and between eight and 25 for Kymijoki (mean = $14, \mathrm{SD}=3.9$ ), depending on lake size and securing proper view of species composition (Kanninen et al. 2013). The surveys were done between June and September over the period 2002-2008. In addition to true hydrophytes (Toivonen and Huttunen 1995), the recorded species also included helophytes, which are ecologically important and valuable in status assessment of boreal lakes (Alahuhta et al. 2011, 2014a).

River macrophytes were sampled using national version of the methodology based on international standard SFS-EN 14184 (Anonymous 2003). At each study reach, two $100 \mathrm{~m}$ sections were surveyed by wading, one slowly flowing site

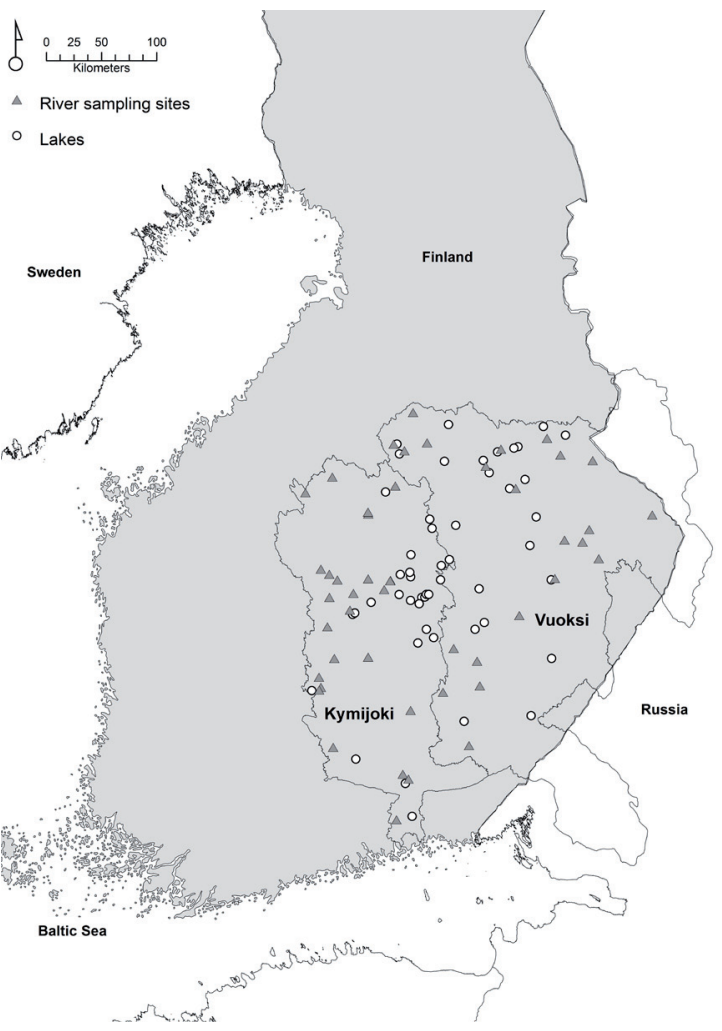

Figure 1. Location of study lakes and river sampling sites in the Vuoksi and Kymijoki river basins in Southern Finland. 
Table 1. Mean and coefficient of variation (in parentheses) of local and catchment variables measured in lakes and river sites across and within Vuoksi and Kymijoki river basins in Finland.

\begin{tabular}{|c|c|c|c|c|c|c|}
\hline & \multicolumn{2}{|c|}{ Across river basins } & \multicolumn{2}{|c|}{ Vuoksi } & \multicolumn{2}{|c|}{ Kymijoki } \\
\hline & Lakes & River sites & Lakes & River sites & Lakes & River sites \\
\hline Number & 48 & 47 & 24 & 22 & 24 & 25 \\
\hline \multicolumn{7}{|l|}{ Local variables } \\
\hline Alkalinity (mmol1-1) & $\begin{array}{r}0.19 \\
(89.28)\end{array}$ & $\begin{array}{r}0.17 \\
(63.73)\end{array}$ & $\begin{array}{r}0.18 \\
(112.03)\end{array}$ & $\begin{array}{r}0.15 \\
(65.55)\end{array}$ & $\begin{array}{r}0.21 \\
(67.28)\end{array}$ & $\begin{array}{r}0.18 \\
(61.21)\end{array}$ \\
\hline Altitude (m.a.s.l.) & $\begin{array}{r}113.43 \\
(27.99)\end{array}$ & $\begin{array}{r}108.85 \\
(28.14)\end{array}$ & $\begin{array}{r}121.96 \\
(30.06)\end{array}$ & $\begin{array}{r}115.58 \\
(27.31)\end{array}$ & $\begin{array}{r}104.90 \\
(21.89)\end{array}$ & $\begin{array}{r}103.15 \\
(27.74)\end{array}$ \\
\hline Channel width (m) & - & $\begin{array}{r}19.87 \\
(105.06)\end{array}$ & - & $\begin{array}{r}16.08 \\
(61.90)\end{array}$ & - & $\begin{array}{r}23.07 \\
(114.52)\end{array}$ \\
\hline Conductivity $\left(\mathrm{mS} \mathrm{m}^{-1}\right)$ & $\begin{array}{r}4.71 \\
(73.87)\end{array}$ & $\begin{array}{r}4.51 \\
(81.10)\end{array}$ & $\begin{array}{r}4.47 \\
(92.22)\end{array}$ & $\begin{array}{r}3.84 \\
(52.08)\end{array}$ & $\begin{array}{r}4.94 \\
(53.77)\end{array}$ & $\begin{array}{r}2.80 \\
(89.43)\end{array}$ \\
\hline Colour (mg PT 1-1) & $\begin{array}{r}101.35 \\
(76.02)\end{array}$ & $\begin{array}{r}128.90 \\
(75.04)\end{array}$ & $\begin{array}{r}126.20 \\
(74.00)\end{array}$ & $\begin{array}{r}171.36 \\
(62.44)\end{array}$ & $\begin{array}{r}76.50 \\
(57.23)\end{array}$ & $\begin{array}{r}92.96 \\
(74.28)\end{array}$ \\
\hline Maximum depth (m) & $\begin{array}{r}16.31 \\
(107.21)\end{array}$ & - & $\begin{array}{r}16.79 \\
(111.66)\end{array}$ & - & $\begin{array}{r}15.83 \\
(101.78)\end{array}$ & - \\
\hline $\mathrm{pH}$ & $\begin{array}{r}6.81 \\
(8.42)\end{array}$ & $\begin{array}{r}6.63 \\
(7.73)\end{array}$ & $\begin{array}{r}6.71 \\
(9.31)\end{array}$ & $\begin{array}{r}6.48 \\
(8.78)\end{array}$ & $\begin{array}{r}6.91 \\
(7.19)\end{array}$ & $\begin{array}{r}6.76 \\
(6.18)\end{array}$ \\
\hline Secchi depth (m) & $\begin{array}{r}2.09 \\
(64.12)\end{array}$ & - & $\begin{array}{r}2.03 \\
(73.72)\end{array}$ & - & $\begin{array}{r}2.15 \\
(53.99)\end{array}$ & - \\
\hline Shoreline length (km) & $\begin{array}{r}55.59 \\
(315.16)\end{array}$ & - & $\begin{array}{r}60.28 \\
(351.95)\end{array}$ & - & $\begin{array}{r}50.91 \\
(251.13)\end{array}$ & - \\
\hline Lake surface area (ha) & $\begin{array}{r}1258.94 \\
(335.08)\end{array}$ & - & $\begin{array}{r}1204.87 \\
(375.85)\end{array}$ & - & $\begin{array}{r}1313.01 \\
(295.73)\end{array}$ & - \\
\hline Turbidity (PTU) & $\begin{array}{r}4.15 \\
(270.49)\end{array}$ & $\begin{array}{r}2.96 \\
(112.11)\end{array}$ & $\begin{array}{r}2.78 \\
(95.01)\end{array}$ & $\begin{array}{r}3.14 \\
(106.74)\end{array}$ & $\begin{array}{r}5.52 \\
(281.46)\end{array}$ & $\begin{array}{r}2.80 \\
(116.90)\end{array}$ \\
\hline Total nitrogen $\left(\mu \mathrm{g} \mathrm{l}^{-1}\right)$ & $\begin{array}{r}594.05 \\
(60.61)\end{array}$ & $\begin{array}{r}519.17 \\
(41.08)\end{array}$ & $\begin{array}{r}582.70 \\
(50.01)\end{array}$ & $\begin{array}{r}526.82 \\
(41.49)\end{array}$ & $\begin{array}{r}605.40 \\
(68.92)\end{array}$ & $\begin{array}{r}512.69 \\
(40.66)\end{array}$ \\
\hline $\begin{array}{l}\text { Total phosphorus } \\
\left(\mu \mathrm{g} \mathrm{l}^{-1}\right)\end{array}$ & $\begin{array}{r}28.88 \\
(107.73)\end{array}$ & $\begin{array}{r}22.94 \\
(83.18)\end{array}$ & $\begin{array}{r}31.00 \\
(87.75)\end{array}$ & $\begin{array}{r}26.45 \\
(90.21)\end{array}$ & $\begin{array}{r}26.76 \\
(128.75)\end{array}$ & $\begin{array}{r}19.96 \\
(65.48)\end{array}$ \\
\hline \multicolumn{7}{|l|}{ Catchment variables } \\
\hline $\begin{array}{l}\text { Size of catchment area } \\
\left(\mathrm{km}^{2}\right)\end{array}$ & $\begin{array}{r}1101.96 \\
(3.85)\end{array}$ & $\begin{array}{r}727.17 \\
(2.02)\end{array}$ & $\begin{array}{r}503.41 \\
(2.89)\end{array}$ & $\begin{array}{r}269.36 \\
(1.17)\end{array}$ & $\begin{array}{r}1613.30 \\
(3.50)\end{array}$ & $\begin{array}{r}1130.04 \\
(1.68)\end{array}$ \\
\hline $\begin{array}{l}\text { Urban development } \\
(\%)\end{array}$ & $\begin{array}{r}3.07 \\
(83.45)\end{array}$ & $\begin{array}{r}2.57 \\
(65.68)\end{array}$ & $\begin{array}{r}2.78 \\
(78.25)\end{array}$ & $\begin{array}{r}1.83 \\
(88.63)\end{array}$ & $\begin{array}{r}3.36 \\
(85.40)\end{array}$ & $\begin{array}{r}3.20 \\
(46.19)\end{array}$ \\
\hline Agriculture (\%) & $\begin{array}{r}7.51 \\
(130.51)\end{array}$ & $\begin{array}{r}5.40 \\
(126.60)\end{array}$ & $\begin{array}{r}6.99 \\
(142.52)\end{array}$ & $\begin{array}{r}3.40 \\
(106.34)\end{array}$ & $\begin{array}{r}8.04 \\
(119.69)\end{array}$ & $\begin{array}{r}7.09 \\
(117.12)\end{array}$ \\
\hline Forests $(\%)$ & $\begin{array}{r}57.66 \\
(17.93)\end{array}$ & $\begin{array}{r}61.48 \\
(11.38)\end{array}$ & $\begin{array}{r}57.44 \\
(15.70)\end{array}$ & $\begin{array}{r}64.29 \\
(10.69)\end{array}$ & $\begin{array}{r}57.87 \\
(19.87)\end{array}$ & $\begin{array}{r}59.11 \\
(10.45)\end{array}$ \\
\hline Waters $(\%)$ & $\begin{array}{r}11.27 \\
(61.04)\end{array}$ & $\begin{array}{r}8.84 \\
(78.12)\end{array}$ & $\begin{array}{r}9.57 \\
(56.88)\end{array}$ & $\begin{array}{r}6.78 \\
(92.72)\end{array}$ & $\begin{array}{r}12.97 \\
(59.35)\end{array}$ & $\begin{array}{r}10.59 \\
(65.44)\end{array}$ \\
\hline Wetlands (\%) & $\begin{array}{r}3.39 \\
(138.36)\end{array}$ & $\begin{array}{r}3.91 \\
(120.04)\end{array}$ & $\begin{array}{r}5.08 \\
(103.37)\end{array}$ & $\begin{array}{r}5.07 \\
(82.22)\end{array}$ & $\begin{array}{r}1.69 \\
(192.16)\end{array}$ & $\begin{array}{r}2.93 \\
(166.84)\end{array}$ \\
\hline
\end{tabular}

(pool) and one swiftly flowing riffle section. A rake was used to reach the macrophytes whenever the stream was too deep or current too strong for wading. Only in-stream macrophytes were recorded, including mosses growing on in-stream stones above water surface. $100 \mathrm{~m}$ sections were subdivided into five $20 \mathrm{~m}$ subsections, where abundance and frequency of each vascular plant species were estimated.

The moss species were recorded from separate $1 \mathrm{~m} \times 2$ $\mathrm{m}$ plots. Ten plots were placed in each $100 \mathrm{~m}$ river section and they were placed systematically: every other placed at the margins of the stream and every other to the mid-stream. The plots were placed at intervals of $10 \mathrm{~m}$, beginning from $5 \mathrm{~m}$ distance of the downstream beginning of $100 \mathrm{~m}$ section. The coverage of each moss species was estimated from each plot.
The river macrophyte surveys were done between June and September over the period 2009-2012.

Our macrophyte data was sampled over several years, however, we consider that comparability between surveys across years is sufficient enough to yield reliable results due to standardised methodology of field teams consisting partly of authors of this study. Despite of zonation patterns and abundances of macrophyte species change over the years, occurrence of species is fairly stable in boreal water bodies with relatively modest anthropogenic pressures and limited number of invasive species (Rintanen 1996). For this reason we used species frequency calculated as a share of the transects with the species recorded. To make lake and river values comparable, we used the percentage scale $0-100 \%$. 


\section{Explanatory variables}

The explanatory variables were divided into three groups: local environment, catchment land cover and spatial variables (Table 1). Local and catchment variables represented most important environmental variables for aquatic macrophytes (Lacoul and Freedman 2006, Alahuhta 2015). For both lakes and rivers, for local variables we included mean altitude (m.a.s.1.), alkalinity ( $\left.\mathrm{mmol}^{-1}\right)$, turbidity (FTU), colour (mg Pt $\left.1^{-1}\right)$, total phosphorus $\left(\mu \mathrm{g} \mathrm{l}^{-1}\right)$, total nitrogen $\left(\mu \mathrm{g} \mathrm{l}^{-1}\right)$, conductivity $\left(\mathrm{mS} \mathrm{m}^{-1}\right)$ and $\mathrm{pH}$. Surface area (ha), length of shoreline $(\mathrm{km})$, maximum depth $(\mathrm{m})$ and Secchi depth transparency (m) were also among local variables for lakes, and channel width $(\mathrm{m})$ for rivers. For all water quality variables, we used median values for surface samples $(<2 \mathrm{~m})$ during the growing season (June-September) over the period 2000-2008 for lakes and 2006-2012 for rivers (data from the Hertta database of the Finnish Environment Institute). Catchment variables consisted of urban development (\%), agriculture (\%), forests $(\%)$, wetlands $(\%)$, waters $(\%)$ and size of catchment area $\left(\mathrm{km}^{2}\right)$ for both lakes and rivers. The proportion of land cover variables within catchment were derived from CORINE land cover database with $25 \mathrm{~m}$ resolution. The catchment variables were prepared using ArcGIS 10 (Esri Corp., Redlands, CA, USA).

Spatial structures among water bodies were studied using Principle Coordinates of Neighbour Matrices (PCNM, Dray et al. 2006), which are obtained from the spectral decomposition of a truncated distance matrix of the spatial relationships among sampling locations. The variables resulting from PCNMs are mutually orthogonal and linearly unrelated spatial variables, and they are able to address complex patterns of spatial variation (Borcard et al. 2011). The first eigenvectors represent broad-scale variation, whereas the ones with small eigenvalues represent finer-scale variation. Significant spatial variation manifested in PCNMs may be a consequence of environmental autocorrelation, dispersal limitation or historical effects on aquatic species composition (Dray et al. 2012). We used two alternative ways to calculate distances between study locations: overland (Euclidean) and watercourse distances. For overland distances, the geographical coordinates of the centre of each lake or river sampling site to calculate overland distances between study locations. Watercourses were based on the most accurate stream network data found in Finland (1:10 000), covering ponds, lakes and over 2 meter wider rivers. We calculated watercourse distances using OD Cost matric of Network Analyst extension in ArcGIS 10. Minimum truncation distances and only positive eigenvectors were employed in this study. Separate PCNM analyses were run for each river basin and across river basins to obtain independent spatial variables specific for each study extent. PCNMs were constructed using the PCNM package in the R environment (Dray et al. 2006).

\section{Statistical analyses}

We used partial redundancy analyses (pRDA) to distinguish the relationships between variation in macrophytes and explanatory variable groups. First, species data was Hellinger transformed to account for numerous zero values and making the data suitable for linear methods (Legendre and Gallagher 2001). The Hellinger distance is a Euclidean distance on site vectors, where the frequency values are first divided by the site total frequency, and the result is square root transformed (Borcard et al. 2011). This transformation reduces the importance of large frequencies. In addition, explanatory variables were $\log$ transformed if it improved normality. Total variation in macrophyte community composition was partitioned to eight fractions, following the protocol of Borcard et al (1992). The partitioned fractions were (a) pure effect of local variables, (b) pure effect of catchment, (c) pure effect of space; combined variation due to the joint effects of (d) local and catchment variables, (e) local variables and space, (f) catchment and space, and (g) the three groups of explanatory variables; and finally (h) unexplained variation. The detailed procedures to estimate these fractions are explained in wellknown literacy (Legendre et al. 2005, Borcard et al. 2011).

Variation explained by each variable group was evaluated with adjusted $\mathrm{R}^{2}$, which provides unbiased estimates of the explained variation (Peres-Neto et al. 2006). In forward selection, type I error can be avoided by using adjusted $\mathrm{R}^{2}$ values, which are also comparable between different models as the number of explanatory variable is taken into account (Blanchet et al. 2008). The use of adjusted $\mathrm{R}^{2}$ values often results to low percentage of variation explained and a considerable amount of unexplained variation (Beisner et al. 2006). However, adjusted $\mathrm{R}^{2}$ values are most suitable for our study design, in which we compare results from different habitats and spatial extents. Following the procedure of Blanchet et al. (2008), forward selection was based on two stopping criterion: either $\mathrm{p}>0.05$ or the adjusted $\mathrm{R}^{2}$ value of the reduced model exceeded that of the global model. Forward selection using the Monte Carlo permutation test ( 999 permutations, a $=0.05$ ) was then used to obtain significant variables for our analyses. All pRDAs were performed in the R environment with Packfor and Vegan packages (Oksanen et al. 2012).

\section{Results}

The number of observed macrophyte taxa was 80 and 84 in lakes in Vuoksi and Kymijoki river basins, respectively. The total number of taxa in lakes was 94 . The number of observed species in rivers was 60 in Vuoksi and 66 in Kymijoki river basins, representing a total of 84 species. 46 species were common for both lakes and rivers. The total variation explained ranged from $33.2 \%$ to $40.0 \%$ for lakes and from $13.7 \%$ to $19.1 \%$ for rivers (Figure 2). Across the river basins, local variables of the pure fractions contributed the most for macrophyte community composition (lakes: $10.2 \%$, rivers: $2.6 \%$ ). Considering joint fractions across river basins, local and catchment variables had the highest influence on the lake $(12.2 \%)$ and river $(11.7 \%)$ macrophytes. In addition, pure fraction of catchment variables was considerable for lake macrophytes $(5.2 \%)$ and joint fraction of all three variable groups was considerable in both the lakes and rivers $(4.1 \%$ and $2.7 \%$, respectively). 
Figure 2. Pure and shared effects of local, catchment and spatial variables based on overland distances in the Vuoksi and Kymijoki river basins. The results are expressed as adjusted percentages of total variation explained in macrophyte community composition data. The significant pure fractions are in bold $(\mathrm{p}<0.05)$.

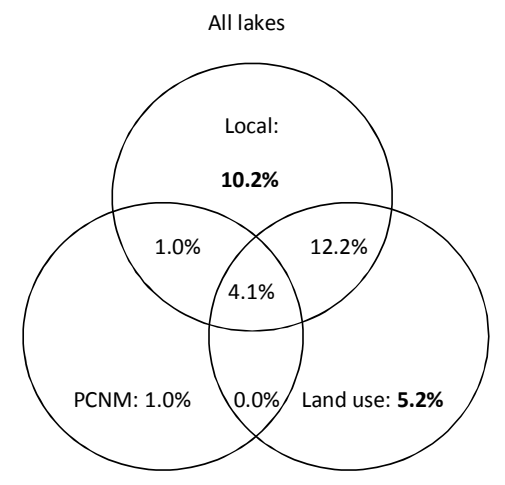

Vuoksi lakes

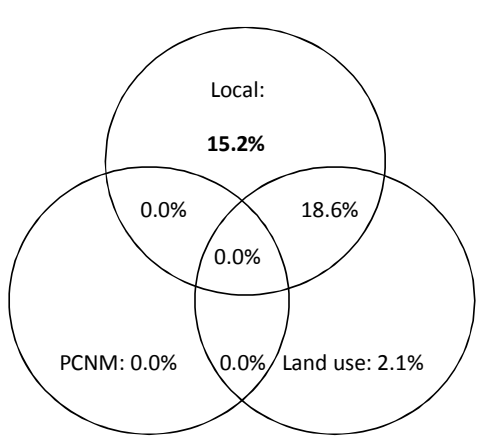

Kymijoki lakes

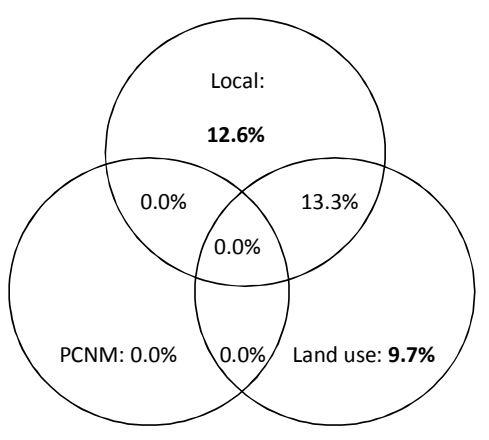

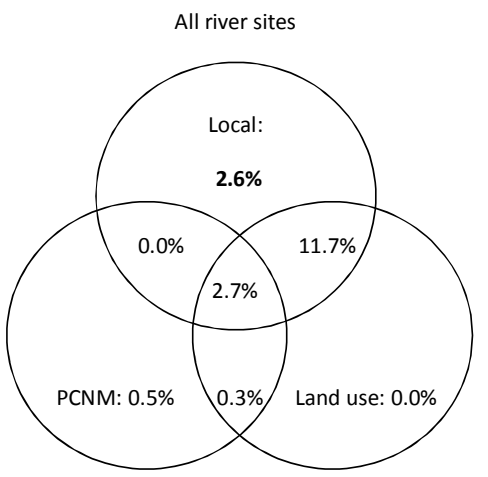

Vuoksi river sites

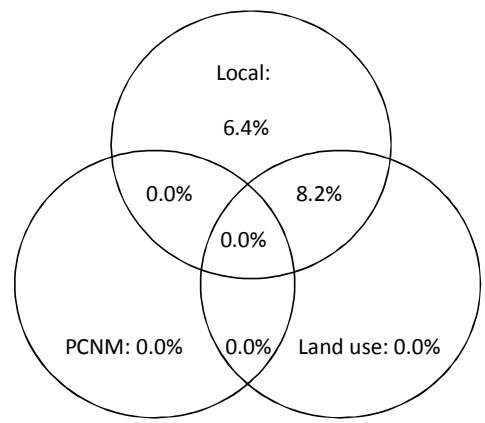

Kymijoki river sites

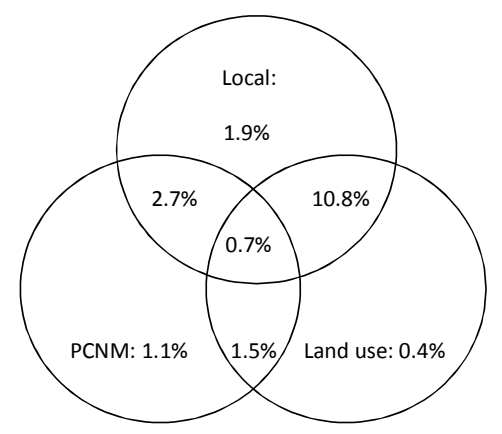

Using Euclidean distances, pure fraction of local variables was important for lake macrophytes $(15.2 \%)$ and also the joint effect of local and catchment variables was significant $(18.6 \%)$ in the Vuoksi river basin. Joint fraction of local and catchment variables had the highest contribution to river macrophytes of Vuoksi river basin in the Euclidean distance models $(8.2 \%)$, followed by local variables $(6.4 \%)$. Considering watercourse distance models in the Vuoksi river basin, pure effect of local variables and joint fraction of local and catchment variables had the highest influence on aquatic macrophytes (lakes: $15.2 \%$ and $18.6 \%$, river sites: $6.4 \%$ and $8.2 \%$, respectively, Fig. 3). For Euclidean distance models in the Kymijoki river basin, local and catchment variables contributed most for lake macrophytes (pure local variables: 12.6\%, pure catchment variables: $9.7 \%$, and joint effect of local and catchment variables: $13.3 \%$ ). Joint effect of local and catchment variables had the highest influence on Kymijoki river macrophytes in the watercourse distance models $(10.8 \%$, respectively).

First and intermediate spatial variables (SV1-SV11) contributed most for both lake and river macrophytes independ- ent of study regions and extents (Table 2). For lake macrophytes, total phosphorus was the most significant local variable across river basins and in the Vuoksi river basin, whereas $\mathrm{pH}$ had the highest contribution for river plants across river basins and Vuoksi river basin. Turbidity influenced most lake flora of Kymijoki river basin, and colour affected strongest to river macrophytes of Kymijoki river basin. In general, catchment area was the most significant catchment variable for all river macrophytes, whereas proportions of water and agriculture at drainage basin had the highest contribution to lake macrophytes of across river basins and Vuoksi river basin. Urban development was the most important catchment variable for Kymijoki lake macrophytes.

\section{Discussion}

\section{Metacommunity structuring of aquatic macrophytes}

In the metacommunity context, the environmental and spatial components of variation can be used as proxies for species sorting and dispersal limitation (Presley et al. 2010, 
Table 2. The significant explanatory variables (i.e., spatial, local and catchment variables) using forward selection by Blanchet et al. (2008) based on adjusted R2 and the Monte Carlo permutation test (999 permutations, $\alpha=0.05$ ). PCNM $=$ Principle Coordinates of Neighbour Matrices. SV = Spatial variable derived from PCNM.

\begin{tabular}{|c|c|c|c|c|c|c|c|c|c|c|c|c|}
\hline \multicolumn{7}{|c|}{ Spatial variables based on Euclidean distances } & \multicolumn{6}{|c|}{ Spatial variables based on watercourse distances } \\
\hline & \multicolumn{3}{|c|}{ Lakes across river basins } & \multicolumn{3}{|c|}{ River sites across river basins } & & & & & & \\
\hline & Variable & $\mathrm{R}^{2} \mathrm{adj}$ & $\mathrm{p}$ & Variable & $\mathrm{R}^{2} \mathrm{adj}$ & $\mathrm{p}$ & & & & & & \\
\hline \multirow[t]{3}{*}{ PCNM } & SV5 & 0.021 & 0.031 & SV7 & 0.025 & 0.007 & & & & & & \\
\hline & SV11 & 0.017 & 0.028 & & & & & & & & & \\
\hline & SV3 & 0.018 & 0.029 & & & & & & & & & \\
\hline \multirow[t]{5}{*}{ Local } & $\begin{array}{l}\text { Total phospho- } \\
\text { rus }\end{array}$ & 0.159 & 0.001 & $\mathrm{pH}$ & 0.084 & 0.001 & & & & & & \\
\hline & Conductivity & 0.057 & 0.001 & River wide & 0.043 & 0.001 & & & & & & \\
\hline & Lake area & 0.023 & 0.001 & $\begin{array}{l}\text { Total phospho- } \\
\text { rus }\end{array}$ & 0.044 & 0.001 & & & & & & \\
\hline & Alkalinity & 0.020 & 0.002 & & & & & & & & & \\
\hline & $\mathrm{pH}$ & 0.013 & 0.004 & & & & & & & & & \\
\hline \multirow[t]{5}{*}{ Catchment } & Waters & 0.110 & 0.001 & Catchment area & 0.074 & 0.001 & & & & & & \\
\hline & Agriculture & 0.071 & 0.001 & Agriculture & 0.040 & 0.001 & & & & & & \\
\hline & Catchment area & 0.019 & 0.005 & Wetlands & 0.030 & 0.004 & & & & & & \\
\hline & Wetlands & 0.009 & 0.038 & & & & & & & & & \\
\hline & \multicolumn{3}{|c|}{ Vuoksi lakes } & \multicolumn{3}{|c|}{ Vuoksi river sites } & \multicolumn{3}{|c|}{ Vuoksi lakes } & Vuoksi & river si & \\
\hline PCNM & - & & & - & & & - & & & - & & \\
\hline \multirow[t]{4}{*}{ Local } & $\begin{array}{l}\text { Total phospho- } \\
\text { rus }\end{array}$ & 0.202 & 0.001 & $\mathrm{pH}$ & 0.067 & 0.002 & $\begin{array}{l}\text { Total phos- } \\
\text { phorus }\end{array}$ & 0.202 & 0.001 & $\mathrm{pH}$ & 0.067 & 0.002 \\
\hline & Conductivity & 0.039 & 0.001 & River wide & 0.041 & 0.002 & Conductivity & 0.039 & 0.001 & River wide & 0.041 & 0.002 \\
\hline & $\mathrm{pH}$ & 0.032 & 0.003 & $\begin{array}{l}\text { Total phospho- } \\
\text { rus }\end{array}$ & 0.038 & 0.016 & $\mathrm{pH}$ & 0.040 & 0.001 & $\begin{array}{l}\text { Total phos- } \\
\text { phorus }\end{array}$ & 0.038 & 0.016 \\
\hline & Alkalinity & 0.030 & 0.01 & & & & Alkalinity & 0.028 & 0.01 & & & \\
\hline \multirow[t]{3}{*}{ Catchment } & Waters & 0.151 & 0.001 & Catchment area & 0.041 & 0.014 & Waters & 0.151 & 0.001 & $\begin{array}{l}\text { Catchment } \\
\text { area }\end{array}$ & 0.041 & 0.014 \\
\hline & Agriculture & 0.056 & 0.001 & Wetlands & 0.032 & 0.037 & Agriculture & 0.056 & 0.001 & Wetlands & 0.032 & 0.037 \\
\hline & \multicolumn{3}{|c|}{ Kymijoki lakes } & \multicolumn{3}{|c|}{ Kymijoki river sites } & \multicolumn{3}{|c|}{ Kymijoki lakes } & \multicolumn{3}{|c|}{ Kymijoki river sites } \\
\hline \multirow[t]{2}{*}{ PCNM } & - & & & SV3 & 0.060 & 0.003 & SV1 & 0.086 & 0.002 & - & & \\
\hline & & & & & & & SV4 & 0.028 & 0.038 & & & \\
\hline \multirow[t]{4}{*}{ Local } & Turbidity & 0.118 & 0.001 & Color & 0.082 & 0.001 & Turbidity & 0.118 & 0.001 & Color & 0.082 & 0.001 \\
\hline & Conductivity & 0.085 & 0.001 & $\mathrm{pH}$ & 0.050 & 0.002 & Conductivity & 0.085 & 0.001 & $\mathrm{pH}$ & 0.050 & 0.002 \\
\hline & Alkalinity & 0.026 & 0.030 & River wide & 0.028 & 0.028 & Alkalinity & 0.026 & 0.041 & River wide & 0.028 & 0.036 \\
\hline & Secchi depth & 0.031 & 0.015 & & & & Secchi depth & 0.031 & 0.021 & & & \\
\hline \multirow[t]{4}{*}{ Catchment } & $\begin{array}{l}\text { Urban develop- } \\
\text { ment }\end{array}$ & 0.108 & 0.002 & Catchment area & 0.086 & 0.001 & $\begin{array}{l}\text { Urban devel- } \\
\text { opment }\end{array}$ & 0.108 & 0.001 & $\begin{array}{l}\text { Catchment } \\
\text { area }\end{array}$ & 0.086 & 0.001 \\
\hline & Waters & 0.071 & 0.010 & Waters & 0.048 & 0.002 & Waters & 0.071 & 0.004 & Waters & 0.048 & 0.002 \\
\hline & Wetlands & 0.027 & 0.037 & & & & Wetlands & 0.027 & 0.030 & & & \\
\hline & Forests & 0.030 & 0.038 & & & & Forests & 0.030 & 0.039 & & & \\
\hline
\end{tabular}

Logue et al. 2011, De Bie et al. 2012), and species sorting in general prevails in structuring communities (Cottenie 2005). The species sorting paradigm emphasises niche patterns, assuming that habitat patches differ with regard to environmental conditions (Logue et al. 2011, Heino et al. 2015). Moreover, resource or environmental gradient influences strongly on the local demography of species and the outcome of local species interactions that site quality and dispersal jointly affect local community composition (Leibold et al. 2004, Heino 2011). As expected, our results gave support for species sorting in determining the variation in lake and river macrophyte community compositions. Environmental variables (i.e., local and 
Figure 3. Pure and shared effects of local, catchment and spatial variables based on watercourse distances in the Vuoksi and Kymijoki river basins. The results are expressed as adjusted percentages of total variation explained in macrophyte community composition data. The significant pure fractions are in bold $(\mathrm{p}<0.05)$. In addition, watercourse distances cannot be determined across river basins.

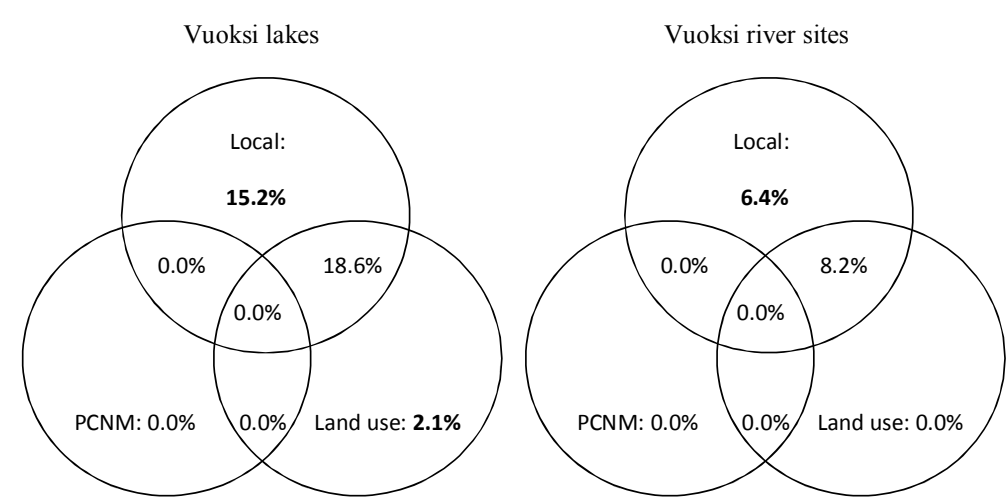

Kymijoki lakes

Kymijoki river sites
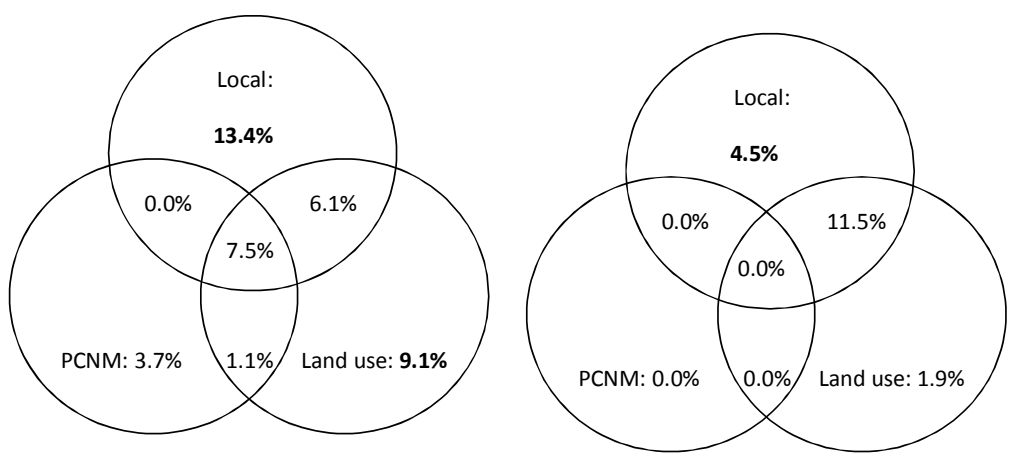

catchment) affected most aquatic macrophytes in both habitats, manifested in the pure effect of local and catchment variables and their joint fractions. The importance of pure space was low or non-existent in our study regions. Species sorting have been found to control macrophyte metacommunites in lakes (O'Hare et al. 2011, Alahuhta et al. 2013, 2014b) and rivers (Heino et al. 2012). The influence of environmental factors is expected to decrease and spatial patterns to increase with increasing spatial extent (Leibold et al. 2004, Bennett et al. 2010). We find little evidence of such a pattern. The significance of pure space increased in across river basin extent compared to river basin extents, although it remained low compared to niche processes. Previous findings on the effect of spatial extent on macrophyte metacommunities have been variable depending on study extent and region (Capers et al. 2010, O'Hare et al. 2011, Mikulyuk et al. 2011, De Bie et al. 2012, Alahuhta and Heino 2013, Alahuhta et al. 2014b). In a study using partly the same data on lake macrophytes, spatial patterns were still clearly overdriven by environmental gradients for the half of Finland (ca. 500 x 500km, Alahuhta et al. 2013). Thus, it is likely that spatial extents of our study were too fine to account for spatial patterns for well-dispersive aquatic macrophytes at large scales, and it may even be that spatial patterns are not dominantly important until at across country or continental extents.

We did not find major differences between lake and river macrophytes in the metacommunity structuring, as niche patterns (i.e., local and catchment) controlled macrophytes in both habitats. Our results for lake macrophytes followed previous studies, however, there is little existing knowledge how river macrophyte metacommunities are structured. Metacommunity paradigms have been investigated for aquatic bryophytes but not for vascular river plants in boreal region (Heino et al. 2012). Running waters are highly disturbed environments for macrophytes, for which e.g., rooting of species to sediment requires additional resources from river plants compared to flora growing in lakes and mechanical stress against stems can be significant (e.g., Bornette and Amoros 1991). Size of catchment area was indeed one of the most significant explanatory variables for river macrophytes showing the effect of river basin area and also disturbance, because catchment size refers to precipitation and therefore similar climatic conditions usually mean similar discharges. In addition, both the number of species and the proportion of vascular plants were lower in rivers than in lakes, likely due to more unstable environment and limited light gradient enhanced by higher humic contents in rivers. On the other hand, flowing water offers good dispersal possibilities for macrophytes, for which spatial patterns should probably be less important in rivers than in isolated lakes (Boedeltje et al. 2004). We did not find, however, any difference between river and lake flora in their response to space, as spatial variables based on overland distances had little or no influence on macrophytes in both habitats.

This finding contradicts with the fact that size of catchment area and proportion of waters, indicating hydrological conditions within a river basin, significantly structured both lake and river macrophytes. Few recent studies have suggest- 
ed that spatial variables based on watercourse distances instead of overland distances can better capture complex spatial patterns for aquatic macrophytes (Landeiro et al. 2011, Padial et al. 2014). However, we found no significant differences in spatial variables based on either overland or watercourse distances, and the influence of spatial variables was overridden by environmental variables in both cases. Our work supports the findings from previous studies that spatial variables based on overland distances can equally well represent intricate spatial patterns for aquatic species with good dispersal capacity (Heino et al. 2012, Grönroos et al. 2013). Colonization strategies and dispersal capabilities of aquatic macrophytes are notoriously efficient (Santamaria 2002, Soons et al. 2008, Viana et al. 2013), leading to multi-continental and cosmopolitan distributions for many aquatic plants (Chambers et al. 2008). Another advantage of overland distances over watercourse distances was that it enabled us to study how spatial extent affects macrophyte community compositions, because watercourse distances cannot be determined across river basins.

There was some variability how spatial patterns based on different distances structured lake and river macrophyte communities. Spatial patterns based on overland distances had no effect on lake macrophytes in the both river basins, however, the contribution of spatial patterns varied for river plant communities between Vuoksi and Kymijoki. River plants in Vuoksi were not affected by spatial patterns based on overland distances, whereas they had some influence on Kymijoki river flora. On the other hand, river plants and Vuoksi lake macrophytes were not affected by spatial variables based on watercourse distances, but spatial patterns based on watercourse distances structured Kymijoki lake flora. These conflicting results are difficult to interpret; however, it seems that spatial patterns are more important in Kymijoki than in Vuoksi river basin. It may be that some spatially structured significant explanatory variable for Kymijoki lake and river macrophytes is not included in our study. A variable describing, for example, discharge may account for the pure spatial fraction for river macrophytes of Kymijoki, because stream hydrology can be an efficient environmental filter in structuring community compositions (Madsen et al. 2001). In addition, other additional explanatory variables (e.g., sediment quality in lakes and rivers and fetch in lakes) important for macrophytes and higher number of water bodies may have increased overall explained variations in all our study regions, although stochasticity is known to strongly influence on macrophyte communities (Capers et al. 2010, Alahuhta et al. 2014b). Thus, inclusion of biotic interactions would also likely have increased explained variations in all the macrophyte models, however, this would have led to very complex models obscuring the primary study purpose. Competition for light and nutrients, for instance, are well-documented for macrophytes (Lacoul and Freedman 2006), and invasive species, like Elodea canadensis Michcx. and Glyceria maxima (Hartm.) Holmb. common in our study sites, can affect native communities.

The used explanatory variables could better describe lake than river macrophytes as the explained variations were constantly higher for lake macrophytes. However, the studied river basins were relatively similar in their environmental conditions (water quality and land cover, see Table 1). These findings suggest that regional specificity is not necessarily strong in our study regions, which are both carrying similar regional species pool after the last Glaciation period (11 000-9000 BP). Southern Finland was part of the large Ancylus Lake after the melting of glacier (Eronen 2005), enabling unrestricted dispersal of species between our river basins. Contrary to our results, Heino et al. (2012) reported a high variability in explaining different freshwater communities between river basins of northern Finland. Regional specificity was also considerable for temperate lake macrophyte communities among several adjunct study regions (Alahuhta and Heino 2013).

\section{Environmental variables explaining aquatic macrophytes}

Lake macrophyte community variation was mostly explained by total phosphorus, conductivity and turbidity of local variables as shown also by Alahuhta et al. (2013) and Alahuhta (2014). Total phosphorus and turbidity are related to trophic status of lakes, whereas conductivity indicates amount of ions in water, such as calcium. Nutrients control especially submerged macrophytes and bryophytes, which take phosphorus and nitrogen directly from water (Toivonen and Huttunen 1995). The trophic status is generally relatively low in boreal freshwaters, for which increase in nutrient concentrations may have increased the number of macrophyte species in lakes. In addition, Birk and Willby (2010) found that conductivity correlated with calcium, which was related to high alkaline condition suitable for macrophytes. Different individual species from the regional species pool can persist in different phosphorus concentrations, further influencing on the variation in the composition of lake macrophyte communities. Agriculture and urban development, along with nutrient-rich soils, contributed to the increased nutrient status of lakes (e.g., Alahuhta et al. 2011).

Of local variables, $\mathrm{pH}$ and river width controlled most significantly variation in community composition of river macrophytes. Boreal waters are naturally acid due to high cover of peatlands. In our study, wetlands were also among the significant variables for across river basins and Vuoksi river basin. River width illustrates hydrological conditions, as discharge is likely stronger in more extensive rivers in landscapes with relatively narrow altitudinal ranges. High amount of suspended sediments and together with mechanical stress of discharge harm distribution of vascular plants (e.g., Bornette and Amoros 1991). In addition, river width indicates habitat availability, as wide rivers likely have different depth zones compared to narrow ones. The size of catchment area and proportion of open water areas were also significant catchment variable for both lake and river flora. These results indicate that habitat availability is an important factor determining lake and river macrophyte communities. For lake plants, habitat availability can influence species in two different extents, as the plants were also affected by lake area. In larger lakes more habitats are available for plant colo- 
nization (van Geest et al. 2003, Capers et al. 2010). Higher proportion of lakes in the catchment means that more potential freshwater bodies are available for plants to grow and feeding downstream ecosystem by propagulates (Boedeltje et al. 2004).

\section{Conclusions}

Metacommunity structuring of lake and river assemblages have been rarely examined simultaneously from the same study area. We found that both lake and river macrophyte communities were structured by environmental patterns, despite different habitat characteristics between lentic and lotic ecosystems. We did not find habitat-related regional specificity in the metacommunity structuring of freshwater macrophytes. Different distance measures did not affect spatial patterns, as spatial variables based on overland and watercourse distances resulted to equally low explained variations. Thus, our results suggest that species sorting is the likely force driving macrophyte communities across different habitats which gives support to the suitability of pressure based assessment systems applied across Europe.

Acknowledgements. We thank Finnish Centres for Economic Development, Transport and the Environment for collecting part of the data. MaaMet-project has contributed to the preparation of this work. The research was partly supported by the project REFORM funded by the European Union under the 7th Framework Programme (contract No. 282656). The comments from three anonymous reviewers were highly appreciated.

\section{References}

Alahuhta, J., K.-M. Vuori and M. Luoto. 2011. Land use, geomorphology and climate as environmental determinants of emergent aquatic macrophytes in boreal catchments. Boreal Environ.Res. 16: 185-202.

Alahuhta, J. and J. Heino. 2013. Spatial extent, regional specificity and metacommunity structuring in lake macrophytes. $J$. Biogeogr. 40: 1572-1582.

Alahuhta, J., A. Kanninen, S. Hellsten, K.-M. Vuori, M. Kuoppala and H. Hämäläinen. 2013. Environmental and spatial correlates of community composition, richness and status of boreal lake macrophytes. Ecol. Indic. 32: 172-181.

Alahuhta, J. 2015. Geographic patterns of lake macrophyte communities and species richness at regional scale. J. Veg. Sci., in press. DOI: $10.1111 /$ jvs. 12261 .

Alahuhta, J., A. Kanninen, S. Hellsten, K.-M. Vuori, M. Kuoppala and H. Hämäläinen. 2014a. Variable response of functional macrophyte groups to lake characteristics, land use and space: implications for bioassessment. Hydrobiologia 737: 201-214.

Alahuhta, J., L.B. Johnson, J. Olker and J. Heino. 2014b. Species sorting determines variation in the community composition of common and rare macrophytes at various spatial extents. Ecol. Complex. 20: 61-68.

Anonymous 2003. SFS-EN 14184 2003. Water quality. Guideline for studying macrophytes in running waters. Finnish Standards Association SFS, Helsinki.
Beisner, B.E., P.R. Peres-Neto, E.S. Lindström, A. Barnett and M.L. Longhi. 2006. The role of environmental and spatial processes in structuring lake communities from bacteria to fish. Ecology 87: 2985-2991.

Bennett, J.R., B.F. Cumming, B.K. Ginn and J.P. Smol. 2010. Broadscale environmental responses and niche conservatism in lacustrine diatom communities. Global Ecol. Biogeogr. 19: 724-732.

Birk, S. and N. Willby. 2010. Towards harmonization of ecological quality classification: establishing common grounds in European macrophyte assessment for rivers. Hydrobiologia 652: 149-163.

Blanchet, F.G., P. Legendre and D. Borcard. 2008. Forward selection of explanatory variables. Ecography 89: 2623-2632.

Boedeltje, G., J. Bakker, A. Ten Brinke, J van Groenendael and M. Soesbergen. 2004. Dispersal phenology of hydrochorous plants in relation to discharge, seed release time and buoyancy of seeds: the flood pulse concept supported. J. Ecol. 92: 786-796.

Borcard, D., P. Legendre and P. Drapeau. 1992. Partialling out the spatial component of ecological variation. Ecology 73: 10451055.

Borcard, D., F. Gillet and P. Legendre. 2011. Numerical Ecology with $R$. Springer, New York.

Bornette, G. and C. Amoros. 1991. Aquatic vegetation and hydrology of a braided river floodplain. J. Veg. Sci. 2: 497-512.

Capers, R.S., R. Selsky and G.J. Bugbee. 2010. The relative importance of local conditions and regional processes in structuring aquatic plant communities. Freshw. Biol. 55: 952-966.

Chambers, P.A., P. Lacoul, K.J. Murphy and S.M. Thomaz. 2008. Global diversity of aquatic macrophytes in freshwater. Hydrobiology 595: 9-26.

Cottenie, K. 2005. Integrating environmental and spatial processes in ecological community dynamics. Ecol. Lett. 8: 1175-1182.

Crump, B.C., H.E. Adams, J.E. Hobbie and G.W. Kling. 2007. Biogeography of bacterioplankton in lakes and streams of an arctic tundra catchment. Ecology 88: 1365-1378.

De Bie, T., L. De Meester, L. Brendonck et al. 2012. Body size and dispersal mode as key traits determining metacommunity structure of aquatic organisms. Ecol. Lett. 15: 740-747.

Dray, S., P. Legendre and P.R. Peres-Neto. 2006. Spatial modelling: a comprehensive framework for principal coordinate analysis of neighbour matrices (PCNM). Ecol. Model. 196: 483-493.

Dray, S., R. Pélissier, P. Couteron, M.J. Fortin, P. Legendre, P.R. Peres-Neto, E. Bellier, R. Bivand, F.G. Blanchet, M. De Caceres, A.B. Dufour, E. Heegaard, T. Jombart, F. Munoz, J. Oksanen, J. Thioulouse and H.H. Wagner. 2012. Community ecology in the age of multivariate multiscale spatial analysis. Ecol. Monogr. 82: 257-275.

Eronen, M. 2005. Land Uplift: Virgin Land from the Sea. In: Seppälä, M. (ed.), The Physical Geography of Fennoscandia. Oxford University Press, Oxford, pp. 17-34.

Grönroos, M., J. Heino, T. Siqueira, V.L. Landeiro, J. Kotanen and L.M. Bini 2013. Metacommunity structuring in stream networks: roles of dispersal mode, distance type, and regional environmental context. Ecol. Evol. 3: 4473-4487.

Heino, J. 2011. A macroecological perspective of diversity patterns in the freshwater realm. Freshw. Biol. 56: 1703-1722.

Heino, J., M. Grönroos, J. Soininen, R. Virtanen and T. Muotka. 2012. Context dependency and metacommunity structuring in boreal headwater streams. Oikos 121: 537-544.

Jacobson, N. and P.R. Peres-Neto. 2010. Quantifying and disentangling dispersal in metacommunities: how close have we come? How far is there to go? Landscape Ecol. 25: 495-507. 
Johnson, R.K., W. Goedkoop and L. Sandin. 2004. Spatial scale and ecological relationships between the macroinvertebrate communities of stony habitats of streams and lakes. Freshw. Biol. 49: 1179-94.

Kanninen, A., V.-M. Vallinkoski, J. Leka, T. J. Marjomäki, S. Hellsten and H. Hämäläinen. 2013. A comparison of two methods for surveying aquatic macrophyte communities in boreal lakes: implications for bioassessment. Aquatic Bot. 104: 88-100.

Lacoul, P. and B. Freedman. 2006. Environmental influences on aquatic plants in freshwater ecosystems. Environ. Rev. 14: 89136.

Landeiro, V.L., W.E. Magnusson, A.S. Melo, H.M.V. Espirito- Santo and L.M. Bini. 2011. Spatial eigenfunction analyses in stream networks: do watercourse and overland distances produce different results? Freshw. Biol. 56: 1184-1192.

Legendre, P. and E.D. Gallagher. 2001. Ecologically meaningful transformations for ordination of species data. Oecologia 129: 271-280.

Legendre, P., D. Borcard and P.R. Peres-Neto. 2005. Analyzing beta diversity: partitioning the spatial variation of community composition data. Ecol. Monogr. 75: 435-450.

Leibold, M.A., M. Holyoak, N. Mouquet, P. Amarasekare, J.M Chase, M.F. Hoopes, R.D. Holt, J.B. Shurin, R. Law, D. Tilman, M. Loreau and A. Gonzalez. 2004. The metacommunity concept: a framework for multi-scale community ecology. Ecol. Lett.7: 601-613.

Logue, J., N. Mouquet, H. Peter, H. Hillebrand and The Metacommunity Working Group. 2011. Empirical approaches to metacommunities: a review and comparison with theory. Trends Ecol. Evol. 26: 482-491.

Madsen, J.D., P.A. Chambers, J.F. James, E.W. Koch and D.F. Westlake. 2001. The interaction between water movement, sediment dynamics and submersed macrophytes. Hydrobiologia 444: 71-84.

Mikulyuk, A., Sharma, S., Van Egeren, S., Erdmann, E., Nault, M.E. and Hauxwell, J. 2011. The relative role of environmental, spatial, and land-use patterns in explaining aquatic macrophyte community composition. Can. J. Fish. Aquatic Sci. 68: 17781789.

O’Hare, M.T., I.D.M. Gunn, D.S. Chapman, B.J. Dudley and B.V. Purse. 2012. Impacts of space, local environment and habitat connectivity on macrophyte communities in conservation lakes. Divers. Distrib. 18: 603-614.

Oksanen, J., F.G. Blanchet, R. Kindt, P. Legendre, P.R. Minchin, R.B. O’Hara, G.L. Simpson, P. Solymos, M.H.H. Stevens and H. Wagner. 2012. vVegan: Community Ecology Package. R package version 2.0-3. Available at: http://CRAN.R-project.org/ package $=$ vegan

Padial, A.A., F. Ceschin, S.A.J. Declerck, L. De Meester, C.C. Bonecker, F.A. Lansac-Toha, L. Rodrigues, L.C. Rodrigues, S. Train, L.F.M. Velho and L.M. Bini. 2014. Dispersal ability determines the role of environmental, spatial and temporal drivers of metacommunity structure. PLOS ONE 9: e111227.

Peres-Neto, P.R., P. Legendre, S. Dray and D. Borcard. 2006 Variation partitioning of species data matrices: estimation and comparison of fractions. Ecology 87: 2614-2625.

Presley, S.J., C.L. Higgins and M.R. Willig. 2010. A comprehensive framework for the evaluation of metacommunity structure. Oikos 119: 908-917.

Riis, T. 2008. Dispersal and colonisation of plants in lowland streams: success rates and bottlenecks. Hydrobiologia 596: 341-351.

Rintanen, T. 1996. Changes in the flora and vegetation of 113 Finnish lakes during 40 years. Ann. Bot. Fenn. 33: 101-122.

Robinson, C. T. and B. Kawecka. 2005. Benthic diatoms of an Alpine stream/lake network in Switzerland. Aquatic Sci. 67: 492-506.

Santamaria, L. 2002. Why are most aquatic plants widely distributed? Dispersal, clonal growth and small-scale heterogeneity in a stressful environment. Acta Oecol. 23: 137-154.

Soininen, J. and J. Weckström. 2009. Diatom community structure along environmental and spatial gradients in lakes and streams. Fundamental Appl. Limnol. 173: 205-213.

Soons, M.B., C. van der Vlugt, B. van Lith, G.W. Heil and M. Klaassen. 2008. Small seed size increases the potential for dispersal of wetland plants by ducks. J. Ecol. 96: 619-627.

Toivonen H. and P. Huttunen. 1995. Aquatic macrophytes and ecological gradients in 57 small lakes in southern Finland. Aquatic Bot. 51: 197-221.

Van Geest, G.J., F.C.J.M. Roozen, H. Coops, R.M.M. Roijackers, A.D. Buijse, E.T.H.M. Peeters and M. Scheffer. 2003. Vegetation abundance in lowland flood plan lakes determined by surface area, age and connectivity. Freshw. Biol. 48: 440-454.

Viana, D.S., L. Santamaria, T.C. Michot and J. Figuerola. 2013 Migratory strategies of waterbirds shape the continental-scale dispersal of aquatic organisms. Ecography 36: 430-438.

Wetzel, R.G. 2001. Limnology, Lake and River Ecosystems. $3^{\text {rd }}$ ed. Academic Press, New York.

Received March 1, 2014 Revised November 28, 2014 Accepted December 12, 2014 